\title{
Development of Phosphate Glass-Ceramics for Biomedical Applications
}

\author{
Toshihiro KASUGA
}

Department of Materials Science and Engineering, Graduate School of Engineering, Nagoya Institute of Technology, Gokiso-cho, Showa-ku, Nagoya 466-8555

\begin{abstract}
Some recent developments of phosphate glass-ceramic biomaterials are briefly reviewed. Bioactive calcium pyrophosphate glass-ceramics can be prepared by including small amounts of $\mathrm{TiO}_{2}$ and $\mathrm{Na}_{2} \mathrm{O}$ (totally $\leq 10$ $\mathrm{mol} \%$ ): they are easy to be machined using conventional tools and they are strongly coated on a $\beta$-type titanium alloy using a conventional glazing technique. These materials are expected to be applicable to some surgical treatments such as custom-made implants, Kirschner-wires and so on. New types of dental materials using phosphate glass-ceramics are also discussed. Phosphate glass-ceramics containing a large amount of $\mathrm{TiO}_{2}(\sim 20 \mathrm{~mol} \%)$ includes a functional Nasicon-type crystal, which has silver-ion exchangeability with excellent chemical durability: they are applied to a castable dental crown with bacteriostatic activity. Phosphate glass-ceramic fillers, which are rapidly sintered by $\mathrm{CO}_{2}$ laser irradiation, have been also newly developed for sealing fissures at the surface of a tooth crown.

[Received May 29, 2007]
\end{abstract}

Key-words : Glass-ceramic, Phosphate glass, Bioactivity, Bacteriostatic activity, Machinable ceramic, Coating, Biomaterial, Dental material

\section{Introduction}

$\mathbf{S}_{\mathrm{lax}}^{\mathrm{I}}$ INCE glass-based materials can be allowed relatively wide latitude in choice of the compositions and the heat-treatment conditions, they have a significant advantage in that they are controllable to improve their chemical and physical properties. Various kinds of glasses and glass-ceramics for biomedical applications include silicate glass-based materials, such as Bioglass ${ }^{\circledR}$ and A-W glass-ceramic which bond with natural bone (i.e., bioactivity). ${ }^{1)}$

Our research group has been studying calcium phosphate glasses and glass-ceramics for biomedical applications. ${ }^{2)}$ Preparation of glass-ceramics containing large amounts of calcium phosphate crystals is believed to be one of the best approaches to obtain materials suitable for biomedical applications. Phosphate glasses have high glass-forming ability and easy shapability. By heating, they are controllable to form functional crystals and improve their microstructures for attaining sufficient performances.

The present review describes three types of calcium titanium phosphate glass-ceramics, as follows: (1) bioactive glassceramics for surgical implants, (2) bacteriostatic glassceramics for dental crown use, and (3) glass-ceramic powders, which can be sintered by irradiating $\mathrm{CO}_{2}$ laser at a low power in a short time, for a dental fissure-sealing treatment.

\section{Bioactive calcium phosphate glass-ceramics}

2.1 Preparation of the glass-ceramics

Calcium phosphate glass-based materials have high potential for use as biomaterials. We believe that it is necessary to obtain phosphate glasses with composition of high $\mathrm{Ca} / \mathrm{P}$ ratio for glass-based materials suitable for implantation.

Although many researchers reported dissolution behaviors in living body of calcium phosphate glasses around the metaphosphate composition, ${ }^{3,4)}$ there were almost no reports on their bioactivity.

In some glasses, anionic groups can be connected through a cation, which should be usually a network modifier, to form the glassy state; such glasses can be called "invert glasses." 5 ) $\mathrm{We}$, for the first time, prepared new types of phosphate invert glasses with compositions of high $\mathrm{CaO}$ and low $\mathrm{P}_{2} \mathrm{O}_{5}$ contents to obtain bioactive materials; the glasses consist of $\mathrm{PO}_{4}{ }^{3-}$ (orthophosphate) and/or $\mathrm{P}_{2} \mathrm{O}_{7}^{4-}$ (pyrophosphate) ions with- out $\mathrm{PO}_{3}^{-}$(metaphosphate) ion and the phosphate groups are connected through $\mathrm{Ca}^{2+}$ ions.

It is difficult to prepare glasses with high $\mathrm{CaO}$ content in the binary $\mathrm{CaO}-\mathrm{P}_{2} \mathrm{O}_{5}$ system using a conventional melt-quenching technique. Glasses with $\mathrm{Ca} / \mathrm{P}>0.75$ in the binary system could not be prepared. Calcium phosphate invert glasses in the pyrophosphate region were obtained by addition of $\mathrm{Na}_{2} \mathrm{O}$ and $\left.\mathrm{TiO}_{2} \cdot{ }^{6}\right)$ The typical compositions are $60 \mathrm{CaO} \cdot 30 \mathrm{P}_{2} \mathrm{O}_{5} \cdot 3 \mathrm{TiO}_{2}$. $7 \mathrm{Na}_{2} \mathrm{O}$ in $\mathrm{mol} \%$. $\mathrm{TiO}_{2}$ addition into phosphate glasses were reported to improve their glass-forming ability and chemical durability. ${ }^{7}{ }^{31} \mathrm{P}$ magic angle spinning nuclear magnetic resonance (MAS-NMR) and laser Raman spectra show that the glass has no long chain phosphate structure and it is an invert glass with pyrophosphate and orthophosphate groups.

Large-sized calcium pyrophosphate glass-ceramics can be prepared by heating the compacts of the phosphate invert glass powders. ${ }^{8)}$ Sintering ability of the calcium pyrophosphate invert glass powders is improved by addition of $\mathrm{Na}_{2} \mathrm{O}$ into the glass composition. ${ }^{9), 10)}$ When $60 \mathrm{CaO} \cdot 30 \mathrm{P}_{2} \mathrm{O}_{5} \cdot 3 \mathrm{TiO}_{2}$. $7 \mathrm{Na}_{2} \mathrm{O}$ glass powders below $10 \mu \mathrm{m}$ were isostatically pressed at a pressure of $100 \mathrm{MPa}$ and subsequently the powder-compacts were heated at $850^{\circ} \mathrm{C}$ in air, dense glass-ceramics with relative densities of $\geq 93 \%$ were prepared. The resulting glassceramics included crystalline phases with bioactivity such as $\beta-\mathrm{Ca}_{3}\left(\mathrm{PO}_{4}\right)_{2}(\beta$-TCP $)$ and $\beta-\mathrm{Ca}_{2} \mathrm{P}_{2} \mathrm{O}_{7}(\beta-\mathrm{CPP})$.

During heating the $60 \mathrm{CaO} \cdot 30 \mathrm{P}_{2} \mathrm{O}_{5} \cdot 3 \mathrm{TiO}_{2} \cdot 7 \mathrm{Na}_{2} \mathrm{O}$ glass powders, calcium phosphate crystals are precipitated at $\sim 650^{\circ} \mathrm{C}$, and subsequently partial melting of the crystalline phases occurs at $\sim 780^{\circ} \mathrm{C}$. The partial melting may be due to reaction of the crystalline phases with residual glassy phase. Large shrinkage of the powder-compact due to sintering starts when temperature is elevated over $800^{\circ} \mathrm{C}$, and it is completed at $\sim 850^{\circ} \mathrm{C}$. The sintering is suggested to be predominantly controlled by viscous flow of the melt formed by the partial melting. ${ }^{8), 9), 11)}$

Transmission electron microscopy (TEM) showed that nanometer-sized glassy particles are embedded in the calcium phosphate phase. ${ }^{12)}$ Energy dispersive spectroscopy (EDS) shows that the glassy phase contains a large amount of titanium with sodium and a small amount of calcium. The glassy phase in nanometer- to micrometer-sizes that is dispersed everywhere in the glass-ceramic plays an important role in sin- 
tering of the glass-ceramic and also in bioactivity.

It was reported that, when most of bioactive materials are soaked in simulated body fluid $\mathrm{SBF}$; an aqueous solution consisting of $\mathrm{Ca}^{2+}: 2.5 \mathrm{mM}, \mathrm{Na}^{+}: 142.0 \mathrm{mM}, \mathrm{Mg}^{2+}: 1.5 \mathrm{mM}$, $\mathrm{K}^{+}: 5.0 \mathrm{mM}, \mathrm{Cl}^{-}: 148.3 \mathrm{mM}, \mathrm{HCO}_{3}{ }^{-}: 4.2 \mathrm{mM}, \mathrm{HPO}_{4}{ }^{2-}: 1.0$ $\mathrm{mM}, \mathrm{SO}_{4}{ }^{2-}: 0.5 \mathrm{mM}$ that include $50.0 \mathrm{mM}\left(\mathrm{CH}_{2} \mathrm{OH}\right)_{3} \mathrm{CNH}_{2}$ and $45.0 \mathrm{mM} \mathrm{HCl}$ at $\mathrm{pH} 7.4)$ at $37^{\circ} \mathrm{C}$, a new calcium phosphate phase that is similar to a calcium-deficient apatite crystal that forms in the living body forms on their surfaces. ${ }^{13)}$

Apatite formed on the $60 \mathrm{CaO} \cdot 30 \mathrm{P}_{2} \mathrm{O}_{5} \cdot 3 \mathrm{TiO}_{2} \cdot 7 \mathrm{Na}_{2} \mathrm{O}$ glassceramic after soaking in SBF for 2 weeks. The new apatite formation is influenced by the durability of the glassy phase in the glass-ceramics. ${ }^{14), 15)}$ Furthermore, $\mathrm{TiO}_{2}$ in the glassy phase may play an important role in the formation of an inducer such as $\mathrm{Ti}-\mathrm{OH}$ for apatite nucleation. ${ }^{16)}$

The apatite-forming ability of the glass-ceramic can be easily improved by autoclaving in water. When the autoclaved sample was soaked in SBF, apatite begins to form after $3 \mathrm{~d}$. During the autoclaving, titanium ions in the amorphous phases around the surface form hydrated titania groups, which play an important role in the apatite formation. ${ }^{17)}$

2.2 Mechanical properties of the glass-ceramics

Fracture toughness, $K_{\mathrm{IC}}$, of the $60 \mathrm{CaO} \cdot 30 \mathrm{P}_{2} \mathrm{O}_{5} \cdot 3 \mathrm{TiO}_{2}$. $7 \mathrm{Na}_{2} \mathrm{O}$ glass-ceramic was estimated to be $\sim 1.8 \mathrm{MPa} \cdot \mathrm{m}^{0.5} .{ }^{8)}$ This value is higher in comparison with that of $\beta$-TCP or hydroxyapatite (HA).18) Bending strength of the glassceramic was estimated to be $\sim 100 \mathrm{MPa}$. When the glassceramic was densified to the relative density of $\sim 99 \%$ using a hot-pressing method, the bending strength increased by $\sim 160$ MPa. ${ }^{19)}$ This value is close to that of human cortical bone. ${ }^{20)}$ Residual pores in the glass-ceramic were drastically reduced both in number and in size.

The glass-ceramic has an great advantage in that it can be easily machined using conventional tools (i.e., machinability); it is not necessary for machining to use diamond tools. Cutting wastes are seen on the glass-ceramic during drilling. Fine machinable calcium pyrophosphate glass-ceramics are prepared by controlling development of the glassy phase. ${ }^{21)}$ One of the possible applications may be a custom-made bioactive implant machined by a CAD/CAM processing.

Figure 1 shows the fracture face of the $60 \mathrm{CaO} \cdot 30 \mathrm{P}_{2} \mathrm{O}_{5}$. $3 \mathrm{TiO}_{2} \cdot 7 \mathrm{Na}_{2} \mathrm{O}$ glass-ceramic. Plate-shaped products of several tens nanometers in thickness are piled up and they are interlocked with one another. ${ }^{21)}$ This morphology is similar to that of the fracture face of mica-based machinable glassceramics. $^{22)}$

The glass-ceramic includes a large amount of $\beta$-CPP crystal. $\beta$-CPP crystal belongs to a tetragonal, space group $P 4_{1} \cdot{ }^{23)}$ The $\mathrm{ab}$ plane is spread by a three-dimensional sheet consisting of $\mathrm{P}_{2} \mathrm{O}_{7}-\mathrm{Ca}$ infinite chains based on the chelate-like rings, giving a matted effect when viewed down $c$-axis. ${ }^{24)}$ The crystal structure of $\beta$-CPP having the matted sheets is believed to be related closely to the cleavability. The easy machinability in the glass-ceramic may imply that $\beta$-PP crystal has cleavability. The machinability is suggested to result from the interlocking plate-like microstructure of $\beta$-CPP crystals dispersed in the glassy matrix phase.

\subsection{Glass-ceramic coating on a titanium alloy}

A new $\beta$-type titanium alloy, Ti-29Nb-13Ta-4.6Zr (TNTZ), has been developed for biomedical applications. ${ }^{25), 26)}$ The alloy shows a high tensile strength of $\sim 1 \mathrm{GPa}$ and low Young's modulus of $60-80 \mathrm{GPa}$. A bioactive calcium pyrophosphate glass-ceramic can be joined strongly with a TNTZ alloy by heating the metal, on which the $60 \mathrm{CaO} \cdot 30 \mathrm{P}_{2} \mathrm{O}_{5}$. $3 \mathrm{TiO}_{2} \cdot 7 \mathrm{Na}_{2} \mathrm{O}$ glass powders are placed, at $800^{\circ} \mathrm{C}$ for $1 \mathrm{~h}$ in

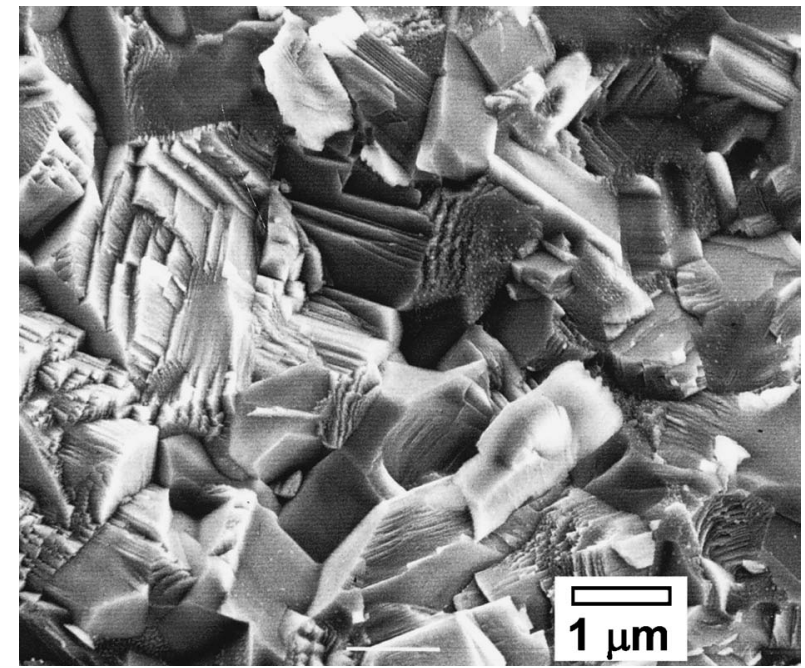

Fig. 1. Scanning electron micrograph $(\mathrm{SEM})$ of the fracture face of the $60 \mathrm{CaO} \cdot 30 \mathrm{P}_{2} \mathrm{O}_{5} \cdot 3 \mathrm{TiO}_{2} \cdot 7 \mathrm{Na}_{2} \mathrm{O}$ glass-ceramic.

air. ${ }^{11), 27), 28}$

The coating layer with $10-20-\mu \mathrm{m}$ thickness was formed under our preparation condition. The tensile joining strength was estimated to be $\sim 26 \mathrm{MPa}$ on average. At the interface between the substrate and the coating layer, there existed a phase with thickness of $\sim 1 \mu \mathrm{m}$ on the substrate. The phase was suggested from EDS analysis to be based on sodium titanium phosphate, which originated from the glassy phase in the glass-ceramic. ${ }^{27)}{ }^{28)}$ The joining between the glass-ceramic and the metal is controlled by viscous flow of the glassy phase in the glass-ceramic and by reaction of the glassy phase with an oxide phase formed around the surface layer of the metal.

Figure 2 shows contact microradiographs (CMR) after 4week and 52-week implantations. The observation showed new bone formation around the autoclaved glass-ceramiccoated TNTZ after 4-week implantation and the bone tissue showed direct contact partially with implants. When the samples after 52-week implantation were sliced and polished for the observation, crack propagation had a tendency to occur between TNTZ (i.e., sample without the coating) and bone, while no crack occurred between the coating and bone. This result shows excellent bioactivity of the glass-ceramic coating on TNTZ. ${ }^{29)}$ This load-bearable glass-ceramic-coated titanium alloy may be applicable to some surgical implants such as Kirschner-wires and so on, which need to have bioactivity and low modulus of elasticity.

\section{Phosphate glass-ceramics with bacteriostatic activity}

Some silver-bearing materials have bacteriostatic activity, that is, effectiveness in inhibiting the growth of microorganisms. These materials have a tendency to release $\mathrm{Ag}^{+}$ions. ${ }^{30}$ ) Extreme release of the ions may be toxic in the human body and shorten the life of the materials.

Silver titanium phosphate Nasicon-type crystals, $\mathrm{AgTi}_{2}$ $\left(\mathrm{PO}_{3}\right)_{4}$, are chemically stable; the $\mathrm{Ag}^{+}$ions are stable in water and in the presence of $\mathrm{Na}^{+}$ions. ${ }^{31)} \mathrm{AgTi}_{2}\left(\mathrm{PO}_{4}\right)_{3}$ crystal can be prepared by exchange of $\mathrm{Ag}^{+}$ion for alkali ion in $\mathrm{MTi}_{2}\left(\mathrm{PO}_{3}\right)_{4}\left(\mathrm{M}^{+}=\mathrm{Li}^{+}\right.$or $\left.\mathrm{Na}^{+}\right)$; it shows excellent bacteriostatic activity. ${ }^{32)}$

High-strength calcium titanium phosphate glass-ceramics containing Nasicon-type crystals with silver-ion exchangeability were prepared: they have the great advantage of bac- 

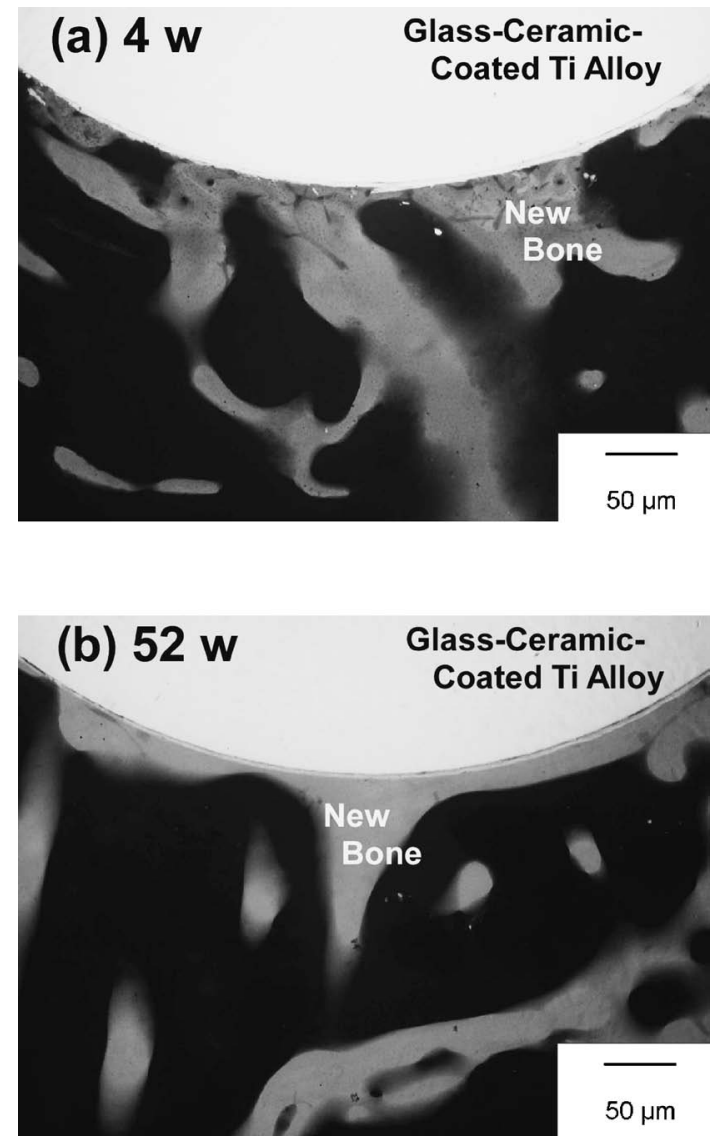

Fig. 2. Contact microradiographs around the glass-ceramic-coated TNTZ (Ti-29Nb-13Ta-4.6Zr) rods of 5-mm diameter implanted into femurs of Japanese rabbits after (a) 4 weeks and (b) 52 weeks.

teriostatic activity given by introducing $\mathrm{Ag}^{+}$ions into their surface layers. Such materials play an important role in the development of dental applications. For example, they are applicable to castable dental crowns utilizing a lost-wax technique. ${ }^{33), 34)}$ Since bacteriostatic activity can be produced locally by the ion-exchange method in portions of the crown, intrusion of bacteria from the gums would be expected to be suppressed effectively. For castable dental crowns, various properties such as high mechanical strength, hardness similar to that of natural dental enamel, good compatibility with the body, and color resemblance are also needed.

We found that a $35 \mathrm{CaO} \cdot 33 \mathrm{P}_{2} \mathrm{O}_{5} \cdot 21 \mathrm{TiO}_{2} \cdot 11 \mathrm{Na}_{2} \mathrm{O}$ glass (mol\%) can be prepared by casting the melt at $1350^{\circ} \mathrm{C}$ and subsequent cooling to room temperature in air. ${ }^{35)}$ The glass was heated from room temperature to $650^{\circ} \mathrm{C}$ and held at this temperature for $20 \mathrm{~h}$ for nucleation, and subsequently it was heated to $700^{\circ} \mathrm{C}$ for $12 \mathrm{~h}$ for crystal growth. No serious defects and deformation were seen in the glass-ceramic. Nasicon-type crystal and $\beta-\mathrm{Ca}_{3}\left(\mathrm{PO}_{4}\right)_{2}$ crystal were precipitated in the glassceramic. The glass-ceramic showed a bending strength of $\sim 160 \mathrm{MPa}$; the strength is comparable to that of conventional castable ceramics for dental crown. ${ }^{33), 34)}$ Vickers hardness of the glass-ceramic was estimated to be $5.5 \mathrm{GPa}$; the value is slightly higher than that of natural tooth but is comparable to that of a conventional dental porcelain. ${ }^{36}$ )

When glass-ceramic grains of $\leq 150 \mu \mathrm{m}$ size were soaked in 1-m $M \mathrm{AgNO}_{3}$ aqueous solution, $\mathrm{Na}^{+}$ions were increased because of dissolution from the material, while $\mathrm{Ag}^{+}$ions were decreased as shown in Fig. 3. The increased amount of $\mathrm{Na}^{+}$

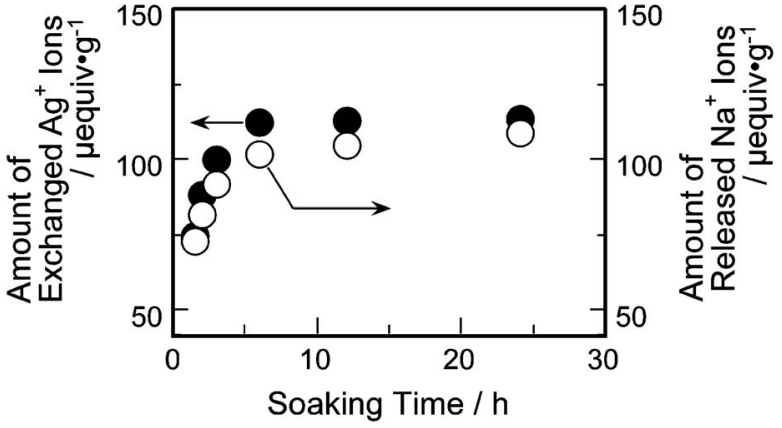

Fig. 3. Amounts of $\mathrm{Ag}^{+}$ion decreased and $\mathrm{Na}^{+}$ion increased by soaking the $35 \mathrm{CaO} \cdot 33 \mathrm{P}_{2} \mathrm{O}_{5} \cdot 21 \mathrm{TiO}_{2} \cdot 11 \mathrm{Na}_{2} \mathrm{O}$ glass-ceramic in $1-\mathrm{mM}$ $\mathrm{AgNO}_{3}$ aqueous solution at $37^{\circ} \mathrm{C}$.
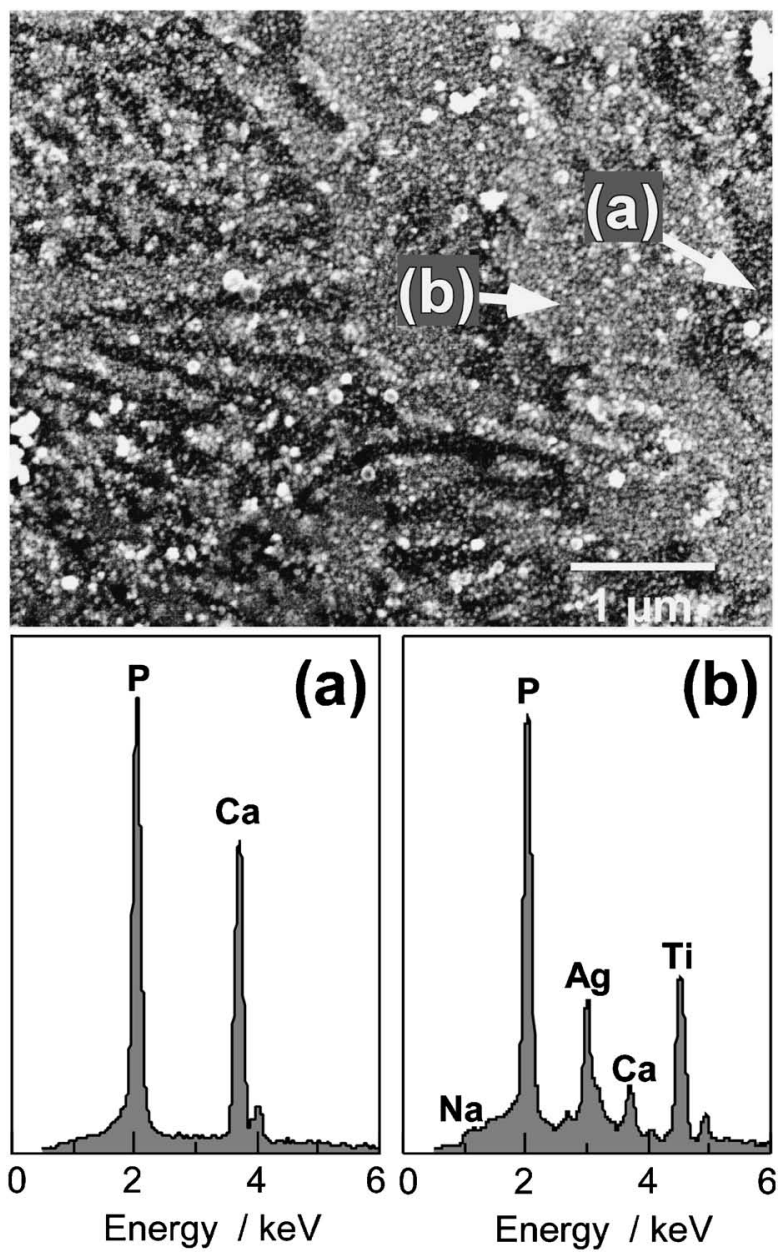

Fig. 4. SEM micrograph of the $35 \mathrm{CaO} \cdot 33 \mathrm{P}_{2} \mathrm{O}_{5} \cdot 21 \mathrm{TiO}_{2} \cdot 11 \mathrm{Na}_{2} \mathrm{O}$ glass-ceramic after soaking in $1-\mathrm{mM} \mathrm{AgNO}_{3}$ aqueous solution at $37^{\circ} \mathrm{C}$ for $24 \mathrm{~h}$ and EDS spectra from the labeled portions in the image.

ions is comparable to the decreased amount of $\mathrm{Ag}^{+}$ions in the solution.

Figure 4 shows an SEM micrograph of the glass-ceramic plate after soaking in $1-\mathrm{mM} \mathrm{AgNO}_{3}$ aqueous solution at $37^{\circ} \mathrm{C}$ for $24 \mathrm{~h}$. The EDS spectra of a slightly dark portion (a) and a bright portion (b) due to the atomic number contrast are also shown. Portion (a) appears to be a calcium phosphate phase, and portion (b) to be a Nasicon-type phase containing 
$\mathrm{Ag}, \mathrm{Na}$, and $\mathrm{Ca}$. Silver is found only in the Nasicon-type phase, (b). Newly formed products were not seen after the soaking. $\mathrm{Na}^{+}$ions in the Nasicon-type phase in the glassceramic are exchanged with $\mathrm{Ag}^{+}$ions to form chemically stable $\mathrm{AgTi}_{2}\left(\mathrm{PO}_{4}\right)_{3} \cdot{ }^{31)}$ Alkali ions in the Nasicon-type crystal are located in sites of the conduction channels. There are two different mobile sites, $A_{1}$ and $A_{2}$. When alkali ions are located in the two sites, the crystal attracts considerable attention as a chemically stable fast ion conductor. ${ }^{37)}$ The mobility of the $\mathrm{Na}^{+}$ions in $\mathrm{NaTi}_{2}\left(\mathrm{PO}_{4}\right)_{3}$ crystals has been reported to be very low. ${ }^{38)}$ However, the electrical conductivities of $\mathrm{Ca}_{1-x} \mathrm{Na}_{2 x} \mathrm{Ti}_{4}$ $\left(\mathrm{PO}_{4}\right)_{6}$ crystals are several orders of magnitude higher than that of $\mathrm{NaTi}_{2}\left(\mathrm{PO}_{4}\right)_{3}$ crystals, since almost immobile $\mathrm{Ca}^{2+}$ ions are located mainly in the stable $\mathrm{A}_{1}$ site and $\mathrm{Na}^{+}$ions are in the mobile $\mathrm{A}_{2}$ site. ${ }^{38)}$ As the Nasicon-type phase in the glassceramic includes $\mathrm{Ca}^{2+}$ and $\mathrm{Na}^{+}$ions, the $\mathrm{Na}^{+}$ions in the conduction channels show high mobility, which is closely related to silver-ion exchangeability.

Evaluation of bacteriostatic activity of the glass-ceramics against Escherichia coli (IFO 3301) was followed by a dropping method. ${ }^{39)}$ The number of the living bacteria included in a phosphate buffer solution (PBS) put on the ion-exchanged glass-ceramic plate was reduced to $<1$ cell after $18 \mathrm{~h}$ of incubation at $36^{\circ} \mathrm{C}$ (initial cell number; $0.2 \times 10^{5}$ cells): excellent bacteriostatic activity was shown. ${ }^{35)}$ The amount of $\mathrm{Ag}^{+}$ions released into the PBS by soaking the glass-ceramic plate for $72 \mathrm{~h}$ at $37^{\circ} \mathrm{C}$ was determined to be below the analytical limit of $<0.1 \mu$ equiv $/ \mathrm{g}$.

\section{Rapid sintering of phosphate glass-ceramic powders by $\mathrm{CO}_{2}$ laser-irradiation}

For prevention of dental caries in milk teeth, fissure sealants using polymers or ionomer cements are often used. Our recent idea is to seal the fissures in permanent teeth using ceramics. The materials for this sealing need multi-performances including good wearing resistance, excellent chemical durability, easy treatment and so on.

$\mathrm{CO}_{2}$ gas laser is applied to some medical treatments, because the thermal diffusion to living tissues of the laser is very low. The laser is effectively adsorbed into phosphate and $\mathrm{OH}$ groups. The possibility of a new type of phosphate glass-ceramic sealant utilizing $\mathrm{CO}_{2}$ laser irradiation is now examined.

A $40 \mathrm{CaO} \cdot 30 \mathrm{P}_{2} \mathrm{O}_{5} \cdot 25 \mathrm{TiO}_{2} \cdot 5 \mathrm{CaF}_{2}$ (in $\mathrm{mol} \%$, denoted by CPT-F) phosphate glass was prepared by a conventional meltquenching method. The resulting glass block was heated at an elevating rate of $5^{\circ} \mathrm{C} / \mathrm{min}$ from room temperature to $700^{\circ} \mathrm{C}$ and held at the temperature for $24 \mathrm{~h}$ for nucleation and subsequently heated to $755^{\circ} \mathrm{C}$ for $12 \mathrm{~h}$ for crystal growth. For a comparative study, $45 \mathrm{CaO} \cdot 30 \mathrm{P}_{2} \mathrm{O}_{5} \cdot 25 \mathrm{TiO}_{2}$ (CPT) glassceramic (without $\mathrm{CaF}_{2}$ ) was also prepared.

The glass-ceramics were etched with $1-\mathrm{N} \mathrm{HCl}$ aqueous solution for $5 \mathrm{~min}$ at room temperature. Almost no CPT-F glassceramic surface was chemically etched, while CPT glassceramic surface was severely etched; numerous small-sized pits were seen. ${ }^{40)}$ The pits were believed to originate from dissolution of crystalline and/or glassy calcium phosphate phases in the glass-ceramic.

CPT glass-ceramic consists of $\mathrm{CaTi}_{4}\left(\mathrm{PO}_{4}\right)_{6}$ and $(\mathrm{TiO})_{2}$ $\mathrm{P}_{2} \mathrm{O}_{7}$ crystals with a calcium phosphate glassy phase. A large amount of Ti constituent is included in the crystalline phases. On the other hand, in CPT-F glass-ceramic, apatite crystal is also precipitated. By addition of fluorine, a large amount of orthophosphate group in the glass is used for the formation of the apatite crystal. As a result, the amount of $\mathrm{CaTi}_{4}\left(\mathrm{PO}_{4}\right)_{6}$
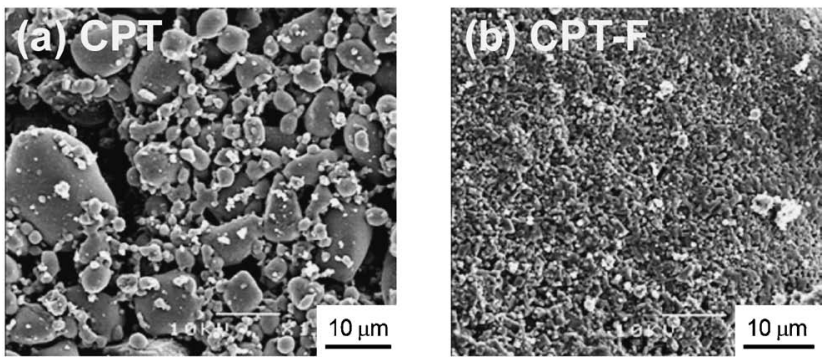

Fig. 5. Glass-ceramic particles of (a) $\mathrm{CPT} \quad\left(45 \mathrm{CaO} \cdot 30 \mathrm{P}_{2} \mathrm{O}_{5}\right.$. $\left.25 \mathrm{TiO}_{2}\right)$ and (b) CPT-F $\left(40 \mathrm{CaO} \cdot 30 \mathrm{P}_{2} \mathrm{O}_{5} \cdot 25 \mathrm{TiO}_{2} \cdot 5 \mathrm{CaF}_{2}\right)$ after $\mathrm{CO}_{2}$ laser irradiation, operated at $2-\mathrm{W}$ power for $5 \mathrm{~s}$.

crystal formed in the glass decreases and the glassy phase include a large amount of $\mathrm{TiO}_{2}$. The glassy phase would be attributed to the improvement of the chemical durability of the glass-ceramic. ${ }^{41)}$ The apatite crystal is considered to include fluorine with almost no hydroxyl group; the crystal is suggested to be the fluoro-oxyapatite phase.

The effect of $\mathrm{CO}_{2}$ laser irradiation on the sintering of the glass-ceramic powders was examined. The glass-ceramics were pulverized into below $10 \mu \mathrm{m}$ in diameter (the average size: $1-1.5 \mu \mathrm{m})$ by using an alumina mortar. The powders were placed on a slide glass plate, and pressed softly by a finger. $\mathrm{CO}_{2}$ laser, operated at $2-\mathrm{W}$ power, was irradiated on the powders for $5 \mathrm{~s}$.

Figure 5 shows the morphologies of the particles after the irradiation. In the case of CPT glass-ceramic powders, the roundish particles are seen, while, in the case of CPT-F glassceramic powders, the surface was densified. By addition of fluorine, the viscosity of a phase melted by the laser irradiation would be lowered, resulting in the enhancement of the densification of the glass-ceramic powders. The glass-ceramic powders are expected to be used for a fissure-sealing treatment. Further investigation is now in progress.

\section{Conclusions}

Phosphate glasses have great potentials in the preparation of high-performance materials, because they have excellent glass-forming ability with easy shapability and are controllable to form functional crystals. Three types of phosphate glass-ceramics for biomedical applications were briefly reviewed.

By heating powder-compacts of the $60 \mathrm{CaO} \cdot 30 \mathrm{P}_{2} \mathrm{O}_{5} \cdot 3 \mathrm{TiO}_{2}$. $7 \mathrm{Na}_{2} \mathrm{O}$ glass, they are crystallized and subsequently are sintered, resulting in the fabrication of high-strength bioactive glass-ceramic with machinability. $\beta-\mathrm{Ca}_{2} \mathrm{P}_{2} \mathrm{O}_{7}$ crystal formed in the glass-ceramic plays an important role in the machinability. The glass-ceramic can be easily coated on a new $\beta$-type titanium alloy using a conventional glazing technique. These materials may be applicable to some surgical treatments such as custom-made implants, Kirschner-wires and so on.

A $35 \mathrm{CaO} \cdot 33 \mathrm{P}_{2} \mathrm{O}_{5} \cdot 21 \mathrm{TiO}_{2} \cdot 11 \mathrm{Na}_{2} \mathrm{O}$ glass-ceramic containing a Nasicon-type crystal showed silver-ion exchangeability. The $\mathrm{Ag}^{+}$-ion-exchanged glass-ceramic showed excellent bacteriostatic activity and a relatively high strength of $160 \mathrm{MPa}$ in bending. This glass-ceramic is expected for applications to castable dental crowns.

A new type of glass-ceramic dental filler, designed especially as a fissure sealant at the surface of a tooth crown, was also developed. The $40 \mathrm{CaO} \cdot 30 \mathrm{P}_{2} \mathrm{O}_{5} \cdot 25 \mathrm{TiO}_{2} \cdot 5 \mathrm{CaF}_{2}$ glass-ceramic included Nasicon-type $\mathrm{CaTi}_{4}\left(\mathrm{PO}_{4}\right)_{6}$, titanium phosphates, 
such as $(\mathrm{TiO})_{2} \mathrm{P}_{2} \mathrm{O}_{7}$ and $\mathrm{Ti}\left(\mathrm{PO}_{3}\right)_{3}$, and $\mathrm{TiO}_{2}$ (anatase) with apatite crystal, which was induced by incorporation of fluorine. The glass-ceramic showed excellent chemical durability. The glass-ceramic powders could be easily sintered by irradiating $\mathrm{CO}_{2}$ laser at a low power in a short time.

These high-performances of the glass-ceramics are generated by the optimum combination of the phosphate crystalline and glassy phases in the materials. Next challenge has been also started; for example, macroporous glass-ceramics are expected to be available to a scaffold for bone tissue engineering. ${ }^{42)}$

\section{References}

1) L. L. Hench and J. Wilson, Science, 226, 630-636 (1984).

2) T. Kasuga, K. Tsuji, Y. Ota, Y. Abe, A. Niimi and M. Ueda, Proc 8th Inter. Symp. Ceramics in Medicine, Ed. by L. L. Hench, J. Wilson and D. Greenspan, Pergamon; Oxford (1995) pp. 415-420.

3) M. Uo, M. Mizuno, Y. Kuboki, A. Makishima and F. Watari, Biomaterials, 19, 2277-2284 (1998).

4) R. M. Pillar, M. J. Filiaggi, J. D. Wells, M. D. Grynpas and R. A. Kandel, Biomaterials, 22, 963-972 (2001).

5) M. K. Murthy, M. J. Smith and A. E. R. Westman, J. Am. Ceram. Soc., 44, 97-105 (1961).

6) T. Kasuga and Y. Abe, J. Non-Cryst. Solids, 243, 70-74 (1999).

7) A. Kishioka, M. Haba and M. Amagasa, Bull. Chem. Soc. Japan, 47, 2493-2496 (1974).

8) T. Kasuga and Y. Abe, J. Mater. Res., 13, 3357-3360 (1998).

9) T. Kasuga and Y. Abe, Proc. 18th Inter. Cong. Glass, Ed. by M. K. Choudhary, N. T. Huff and C. H. Drummond, The American Ceramic Society, Ohio (1998) E4: 31 (CD-ROM).

10) T. Kasuga, M. Nogami and M. Niinomi, Key Eng. Mater., 192-195, 223-226 (2001).

11) T. Kasuga, M. Nogami and M. Niinomi, Adv. Eng. Mater., 5, 498-501 (2003)

12) T. Kasuga, M. Nogami, T. Hattori, M. Niinomi and L. L. Hench, Key Eng. Mater., 284-286, 243-246 (2005).

13) T. Kokubo, J. Non-Cryst. Solids, 120, 138-151 (1990).

14) T. Kasuga, M. Sawada, M. Nogami and Y. Abe, Biomaterials, 20, 1415-1420 (1999).

15) T. Kasuga, M. Nogami and Y. Abe, Phosphorus Res. Bull., 10, 534-539 (1999).

16) T. Kokubo, H.-M. Kim and M. Kawashita, Biomaterials, 24, 2161-2185 (2003).

17) T. Kasuga, T. Fujimoto and M. Nogami, J. Ceram. Soc. Japan, 111, 633-635 (2003)

18 ) H. Aoki, Medical Applications of Hydroxyapatite, IshiyakuEuroAmerica, Tokyo (1994) pp. 286-306.
19) T. Kasuga, M. Nogami and M. Niinomi, J. Mater. Sci. Lett., 20, 1249-1251 (2001).

20) L. L. Hench and J. Wilson, Introduction to Bioceramics, Ed. by L. L. Hench and J. Wilson, World Scientific, Singapore (1993) pp. 1-24.

21) T. Kasuga, M. Terada, M. Nogami and M. Niinomi, J. Mater. Res., 16, 876-880 (2001).

22) T. Kasuga and M. Nogami, Phosphorus Res. Bull., 13, 153-158 (2002).

23 ) D. E. C. Corbridge, Acta Cryst., 10, 85 (1957).

24) N. C. Webb, Acta Cryst., 21, 942-948 (1966).

25) M. Niinomi, Biomaterials, 24, 2673-2683 (2003).

26) M. Niinomi, D. Kuroda, H. Fukui, T. Kasuga, A. Suzuki, K. Kyo and S. Katsura, Recent Res. Devel. Metallug. Mater. Sci., 5, 1-9 (2001).

27) T. Kasuga, T. Mizuno, M. Watanabe, M. Nogami and M. Niinomi, Biomaterials, 22, 577-582 (2001).

28) T. Kasuga, M. Nogami and M. Niinomi, J. Am. Ceram. Soc., 86, 1031-1033 (2003).

29) T. Kasuga, M. Nogami, M. Niinomi, T. Hattori and L. L. Hench, Key Eng. Mater., 284-286, 243-246 (2005).

30) A. Oya, T. Banse, F. Ohashi and S. Otani, Appl. Clay Sci., 6 , 311-18 (1992).

31) T. Kasuga, H. Kume and Y. Abe, J. Am. Ceram. Soc., 80 , 777-80 (1997).

32) H. Hosono and Y. Abe, Mater. Res. Bull., 29, 1157-1162 (1994).

33) P. J. Adair and D. G. Grossman, Int. J. Periodont. Res. Dent., 2, 33-45 (1984).

34) S. Kihara, A. Watanabe and Y. Abe, J. Am. Ceram. Soc., 67, C100-101 (1984).

35) T. Kasuga, M. Nogami and Y. Abe, J. Am. Ceram. Soc., 82, 765-767 (1999).

36) Y. Abe, H. Hosono, M. Hosoe, S. Imura and Y. Tanaka, "Handbook of Bioactive Ceramics Vol. 1," Ed. by T. Yamamuro, L. L. Hench and J. Wilson, CRC Press, Boca Raton (1990) pp. 109-114.

37) H. Aono, E. Sugimoto, Y. Sadaoka, N. Imanaka and G. Adachi, J. Electrochem. Soc., 163, 590-591 (1989).

38) O. Mentre, F. Abraham, B. Deffontaines and P. Vast, Solid State Ionics, 72, 239-299 (1994).

39) K. Hiyama, J. Antibact. Antifungai. Agents, 25, 679-684 (1997).

40) E. Ueno and T. Kasuga, Phosphorus Res. Bull., 19, 280-283 (2005).

41) T. Kasuga, E. Ueno and A. Obata, Key Eng. Mater., 330-332, 157-160 (2007)

42) A. Obata, M. Sasaki and T. Kasuga, Mater. Trans., 48, 313-316 (2007).

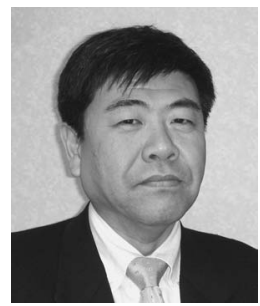

Toshihiro Kasuga is a professor of Nagoya Institute of Technology (NIT), Graduate School of Engineering. He received his B. Eng. and M. Eng. degrees from NIT in 1981 and 1983, respectively, in the area of ceramics engineering and the Dr. Eng. from Osaka University in 1993. Before joining NIT, he worked for HOYA Corporation in 1983-1991. His current research interests are in glass-ceramics and organic-inorganic hybrids for biomaterials and proton conducting materials for clean energy applications. 